\title{
EXPERT SYSTEMS IN THE FUNCTION OF OPTIMIZING SPARE PARTS INVENTORIES IN AUTOMOTIVE INDUSTRY
}

\author{
KAVRAN, Z.; TOMASIC, D. \& SAFRAN, M.
}

Abstract: Inventory management as part of the "production management" system in economic systems of automotive industry is becoming an important element of the overall economic competitiveness. Strong competition and global market environment stipulate the need to use scientific achievements in the inventory management process as the subsystem of the economic sector of automotive industry. The key element of the delivery quality of post-sales services in automotive industry represents a phenomenon of good inventory management. Using an example from practice the paper presents an optimization model of inventory management by means of expert systems.

Key words: expert system, safety inventory, level of service, quality of service
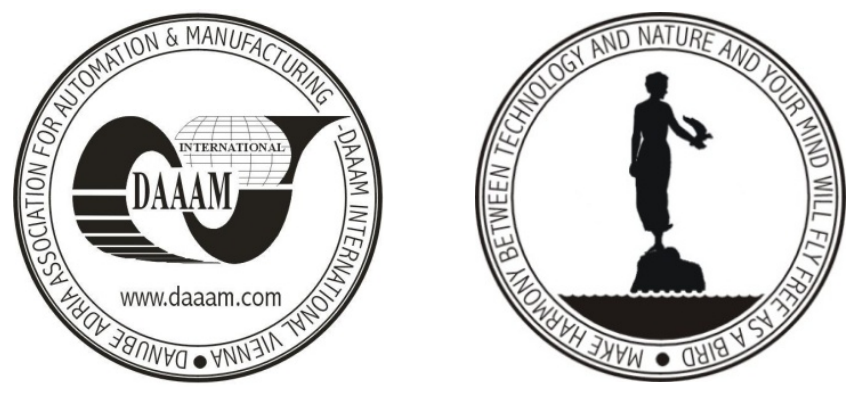

Authors' data: Dr. Kavran, Z[vonko]*; Tomasic, D[ubravko]**; Dr. Safran, $\mathrm{M}[$ ario]*, *Faculty of transport and traffic sciences, Vukelićeva 4, 10000, Zagreb, HR, **Auto Zubak, Josipovićeva 19, 10410, Velika Gorica, HR, dubravko.tomasic@autozubak.hr, mario.safran@fpz.hr, zvonko.kavran@fpz.hr

This Publication has to be referred as: Kavran, Z[vonko]; Tomasic, D[ubravko] \& Safran, M[ario] (2008). Expert Systems in the Function of Optimizing Spare Parts Inventories in Automotive Industry, Chapter 31 in DAAAM International Scientific Book 2008, pp. 359-370, B. Katalinic (Ed.), Published by DAAAM International, ISBN 978-3-901509-66-7, ISSN 1726-9687, Vienna, Austria

DOI: $10.2507 /$ daaam.scibook.2008.31 